\title{
An Assessment of Challenges faced by Microenterprises in Botswana: A case of Street Food Vendors in Gaborone
}

\author{
Nakisani Carol, Chicho-Matenge, MBA \\ Lecturer, Management, \\ Boitekanelo College \\ Department of Healthcare Management, \\ P.O.Box 203156. \\ Gaborone, Botswana \\ Email: nakisanichicho82@yahoo.com
}

\author{
Henry Ongori \\ Senior Lecturer, Management \\ University of Botswana, \\ Faculty of Business \\ Department of Management \\ Private Bag UB 00701 \\ Gaborone, Botswana \\ Phone: 002673555109 \\ Fax: 002673185102 \\ Email: ongorih@mopipi.ub.bw
}

\author{
Accepted: Sep 19, 2013 Published: October 27, 2013 \\ Doi:10.5296/ijld.v3i5.4470 URL: http://dx.doi.org/10.5296/ijld.v3i5.4470
}

\begin{abstract}
Street food vending in urban areas of developing countries like Botswana continues to be a source of livelihoods to many (Joseph, 2011). The Government and relevant stakeholders need to understand holistically the challenges faced by street food vendors and develop interventions that will enable street food vendors to survive, grow and compete in a dynamic business environment.

This study examined the challenges faced by street food vendors in the selected malls of Gaborone and these are Kagiso, African and Main Mall. Further, the study investigated the importance of street vending as a livelihood strategy and strategies to lessen the challenges faced by street vendors. The data was collected from ninety seven street food vendors from the selected sample of the study using a 51 item questionnaire. Data was analyzed with the use of SPSS (Spatial Package for Social Sciences) 16.0 and later on was tabulated for ease interpretation.

The major findings of the study indicated that street food vending is mostly a source of income and a way of creating employment for the urban poor. The study recommends that street food vending needs to be legally recognized. The study would inspire policy makers to come up with specific legislation to promote street food vending business in Botswana.
\end{abstract}


Key words: Street food vendor, challenges, strategies, Botswana

\section{Introduction}

Unemployment has been a key challenging issue in different nations and Botswana is not an exception. According to Labour Force Survey 2005/2006 (2007) unemployment in Botswana stood at $17.5 \%$ and most affected group are the youth and women who make up $34.9 \%$ and $55.4 \%$ of unemployed people respectively. This shows an increase of unemployment rate to $17.8 \%$ as per the Budget Speech of 2012 (Budget Speech, 2012). The unemployment rate along gender lines also indicated an increase where males were $16.3 \%$ and females $23.9 \%$ (UNDP and BIDPA, 2005). The Labour Report (2007) shows that the total formal sector employment for the years 2001 to 2007 showed an increment of $2.4 \%$ and the trend demonstrated that employment's highest proportion was that of males. Oberai (1992) stated that one of the most challenges facing policy makers in Africa today in an era of economic crisis is employment creation. Therefore, unemployment is a challenge to most of developing countries including Botswana.

There is no universal definition for micro enterprises businesses and therefore, the definition varies from to country. Generally, micro enterprises are family owned, employ low levels of skills and are highly labour intensive (Harvie, 2003). Micro enterprises are businesses which are involved in production, trade and provision of services (Pansiri and Temtime, 2005). It can be deduced that micro businesses are categorized on the basis of labour force size and annual turnover (Gwebu, 2005). The smallest units of business of micro business are the street vendors who form part of the informal sector in Botswana.

Micro enterprises form part of the informal sector and it is currently estimated that there are over 50000 operators in Botswana (Gwebu, 2005). Butale (2001) argued that rural-urban migrants who fail to obtain formal employment become disappointed with the search of employment and decide to make out a living through informal sector ways. This leads to significant increase of the informal sector as an alternative means of income generation for many Batswana (UNDP and BIDPA, 2005). Thus street food vendors are therefore, micro enterprises that operate in this informal sector of the economy (Jimu, 2004).

Informal businesses usually cover domestic workers, cobblers, street barbers, street vendors just to name a few (Labour Report, 2007). Moreover, Mitullah (2003a) stated that street vending included shoe repair, hairdressing, commercial payphones, barbering, photocopy, music accessories and selling of agricultural produce. Similarly, Jefferies (2000) noted that micro enterprises are businesses which employ up to six people; however, they practically employ only one or two people including the owner. In Botswana, particularly, micro enterprises create jobs and uplifts people from absolute poverty; therefore, their existence needs recognition (Gobagoba and Littrell, 2003). These enterprises in Botswana make up to $75 \%$ and which most of them are owned by women (Ministry of Commerce and Industry, 1998). It has been noted that these micro enterprises sometimes fail because women frequently face gender bias in the socio-economic environment in which they operate in (Richardson, Howarth and Finnegan, 2004).

Micro enterprises have long been recognized as engines of economic growth and have been put in the development agenda and strategy for many developing countries (Pansiri and Temtime, 2008). They also append that micro enterprises contribute to the economic diversification, employment creation, income generation and poverty alleviation (Pansiri and Temtime, 2008). Cohen and Chen (1997) pointed out that in developing countries micro enterprises employ a significant share of the workforce particularly the female workforce and contribute or generate a significant household income (Gobagoba and Littrell, 2003). For many developing countries, micro enterprises are crucial to the developmental objectives such as poverty alleviation, 
employment creation, individual empowerment and economic development (Cohen and Chen, 1997; LEA, 2009). However, in Botswana this sector has not been well developed and researched in relation to its impact on the economy (UNDP and BIDPA, 2005).

Micro enterprises encompass street vendors who are small traders doing their business in an unstructured way, usually operating from residential premises, alongside the roads and majority of them are run by women who generally lack formal training and registration (Task Force, 1998: Ohiokpehai, 2003). They sell a variety of goods which include food, cosmetics, farm produce, media papers, electronics, and airtime and provide services like plaiting, car wash; car guard and most of them are found in and around shopping malls (Ohiokpehai, 2003). Botswana Government Paper (1999) defined micro enterprises as businesses with less than six workers, with a turnover of less than P60 000. The study adopted the definition by Gobagoba and Littrell (2003), which defined micro enterprises as business with fewer than six employees including the owner. This definition is supported by the Botswana National Policy on SMMEs of 1998. According to the Central Statistics Office (2005), by 1999 there were about $70 \%$ of micro enterprises located in Gaborone and $75 \%$ of these lacked formal registration. Agyapong (2010) argued that most of these micro enterprises are dominated by one person, with the owner or manager taking all major decisions. In addition, owners have limited formal education; access to use and use of latest technology; market information; lack of government support; weak management skills thus restraining the development of the business. Street vending business has become a way of life for those who are unemployed and usually operate in open areas, at home, footpaths, street pavements while others do their business in small enclosed tuck shops (Ohiokpehai, 2003).

The study investigates challenges that are encountered by micro enterprises with special focus on street food vendors in Gaborone selected malls. In addition, the study examines strategies utilized by street food vendors to mitigate the challenges.

\section{Literature Review}

\section{Definition of Street Vendors}

Street vendors are businesses made up of a single person or a household based with family members helping to sell the products (Butale, 2001; Harvie, 2003, Ohiokpahei, 2003),). In addition, Bharan (2004) states that a street vendor is a person who offers goods and services for sale to the public without having a permanent built up structure but with temporary static structure or mobile stall. In Botswana, one can successfully categorize street food vendors into three major groups of snacks, beverages and complete meals (Mpuchane, Gasha, Allotey, Collison and Masheka, 2011). For the purpose of this paper street vendors is defined as a business owner who employs not more than five employees including the owner.

\section{Characteristics of Street Food Vendors}

Like any other informal sector enterprises, street food vending is characterized by the small scale operation, low capital costs that allow ease of entry into the sector (Tinker and Fruge, 1982). It is one sector that is not regulated as it lacks official registration and legal recognition (Mokgosi, 1997; Butale, 2001). According to Muinde and Kuria (2005), street food vendors operate haphazardly without any monitoring of what they prepare and how they do it. Both females and males are involved actively in the activities of street vending and most of the time street trading makes the largest group of micro enterprises (Mitullah, 2003a; Chukuezi, 2010). Somolekae (1992), in her report pointed out that female made the majority of informal enterprises. Street vending which makes one of the major sub sectors is therefore characterized by: five lowly paid employees who include the owner and three or four additional employees; expenditure is not easily distinguishable from household expenditure; operations are usually mobile or in owners home (ISS, 2009). 
Most of these street food vendors operate in make shift structures while some of them are mobile moving from place to place (Mokgosi, 1997; Butale, 2001; Dardano, 2003). These operators do not use permanent structures; however, operate from strategic locations including bus and train stations, markets and shopping areas, commercial districts, outside schools and hospitals, residential suburbs, factories and constructive sites (Draper, 1996). In most of the situations it appears as vendors have regular clientele (Nasinyama, 1992).

Furthermore, typical distinctiveness of street vendors is that they keep few records of business activities, low level of stock is maintained over a short period or no stock is kept, lack of business experience, profits are low, activities are highly labour intensive, earnings fluctuate greatly and there is lack of start-up capital (Linden, 1993; Temtime, Chinyoka and Shunda, 2004; Lowden, 2007).

\section{Roles and Activities of Street Vendors}

Small to medium sized enterprises have long been recognized as key to economic growth and have been put in the development agenda and strategy of many developing African countries (Pansiri and Temtime, 2008). Additionally, micro enterprises have been seen as a potential source of employment for unskilled and semi skilled and income generation for many people (Task Force, 1998; Ohiokpahei, 2003; Onyuma, Birachi, Cheruiyoit and Icart, 2006). Street vendors also act as an economic support to other businesses as they buy and sell goods and services. Similarly, Jimu (2004) adds that street vending provide viable alternatives for subsistence living in urban areas to formal employment. To the unemployed, street vending is their only means of their survival thus leading to the rapid growth of the informal sector mostly in larger cities (Bhowmik, 2003).

Street vending have been less researched on, as it is not officially permitted and vendors are often harassed by government officials especially the unlicensed (Bhowmik, 2003; Ohiokpehai, 2003). Some of the street vendors in particular, provide their goods and services to both working class and professionals especially in Botswana; these goods and services include food, cosmetics, farm produce, media papers, electronics, and airtime; plaiting, car wash, car guard respectively.

In other countries like Nigeria, Ghana, Kenya and including Botswana, the majority of vendors are women who balance the income generating from street vending with traditional household and child care duties (Mwangi, 2002; Akinyele, 1987). Street vending provides marginalized people with access to an income, though irregular, it is still vital for household survival (Bunjun, 1988). This spirit of entrepreneurship promotes a culture of self-reliance, personal responsibility and creation of employment opportunities (Leighton and Folstead 1992. According to Bunjun (1988), the role of the informal sector is that it helps the government in its efforts of employment creation and maintaining a balance between urban and rural growth.

\section{Importance of Street vendors in Botswana}

Street vendors create economic resources to sustain themselves because urban development's efforts fail to provide formal employment (Tripp, 1997). A livelihood is sustainable when it can cope with challenges and maintain or enhance its capabilities and assets (Joseph, 2011). Successful Street vending as a form of diversification is generally recognized as an important strategy for decreasing livelihood challenges or vulnerability (Joseph, 2011). There is an increase in people turning to informal sector for their livelihood (Farrington, 2001). Street vending provide employment and income as a livelihood strategy for the urban poor, it is therefore, a dynamic process in which people engage to construct their livelihood (United Nations, 2003). 


\section{Challenges faced by street vendors businesses}

Beyond economic capability, street vendors are entrenched in a web of complex livelihood challenges, which go beyond self empowerment (Tripp, 1997; Joseph, 2011). They are subjected to repressive planning legislation which excludes them from street trading (Linden, 1993; Joseph, 2011, BIDPA, 2011).

According to the 2007 Informal Sector Survey (2009), many street vendors enterprises in Botswana are faced with the following challenges; non-payment of goods and services supplied on credit to their customers; high competition, lack of managerial skills which were the most constraints among operators, lack of space for business operations and lack of credit facilities.

Post (1996) noted that, though street vendors are one of the highly visible informal sector activities, street vending is mostly unregulated trading that takes place in public spaces such as streets, sidewalks, bridges, pavements etc. The use of public space in Botswana both physically and socially by street vendors has become the subject of intense contestation (Joseph, 2011). In many African countries street vending is perceived as a major crisis and an eye-sore in the urban authorities and criticized for causing or contributing to a number of social ills that negatively affect cities (Palmer, 2007).

Most of the policies and programs formulated lack coordination and ultimately lead to poor management and failure of use of funds by these micro enterprises (Acquah and Mosimanegape, 2007; Pansiri and Temtime 2008). Most street vendors or micro traders depend on owner savings for initial investment and others relied on loans from relatives and friends. Commercial banks were reluctant to lend money to small scale business as they lacked business skills, had high cost risk and that small business emphasized on short term survival issues while banks were for long-term competitiveness (Gwebu, 2005; Pansiri and Temtime 2005). Botswana government and the private sector have been assisting micro enterprises but not paying much attention on the component of training small business owners on how to manage their businesses for long term survival in the market (Gobagoba and Littrell, 2003; BIDPA and CEDA, 2007.

In developing countries urban planners formulate policies to control the operation of the informal sector activities particularly street vending (Palmer, 2007) but some of these policies are not friendly to street vendors (Palmer, 2007; Joseph, 2011). For instance, they carry out frequent inspection and do demolitions, confiscation of goods and sometimes remove some street vendors from where they operate (Joseph, 2011). Furthermore, restrictive bureaucratic regulations are some of the challenges that affect street vendors and lack of facilities to conduct their business (Linden, 1993).

Due to competition street vendors sometimes as a way of attracting customers, they sell their products at low prices which in turn a lead to reduced profits ((Sekar, 2007; Bhat and Nengroo, 2013, Mmusi, 1995; Mokgosi, 1997; Jimu, 2004; Fuller-Love, 2006). Furthermore, there is lack of appropriate land zones gazetted specifically for street vending in Gaborone (Joseph, 2011). Location preferences for street vending enterprises are customer driven such that the officially poorly zoned market area at Bontleng, becomes unattractive to even the new entrants (Joseph, 2011; BIDPA, 2011). Moreover, urban planners are reluctant to organize spaces such as market stalls within street vendors' site of preference (Joseph, 2011; Monnaesi, 2011).

Joseph (2003) indicated that there was lack of definite statutes, disjunction between licensing and land requirements, lack of consultation, environmental and public health concerns. Street vending and other informal sector activities in Botswana are managed using clauses found in legislations drawn to address different issues such as public health, food control, and environmental management (Joseph, 2003; Joseph, 2011). The legislations include among others the Public Health Act of 1971, Food Control Act of 1993, Trade and Liquor Act of 1986, and Waste Management Act of 1998 (Mpuchane et al., 2001; Ohiokpehai, 2003; Joseph, 2003). 
The only available piece of legislation which attempts to address the issue of street vending is The Town Council Hawking and Street Vending Regulations of 1985 which is concerned only with penalties to those people who disregard the provisions of the clauses (Joseph, 2011).

There is lack of inspection on health issues and poor hygiene practices tend to pose significant health risks to street vendors (Arambullo et al., 1994). They also highlighted that there are health risks in preparation and handling of food (Arambullo et al., 1994; Sekar, 2007; Solomon-Ayed et al., 2011). The food can be contaminated with bacteria as some food lack covering (Solomon-Ayed et al., 2011). There is issue waste water which is usually splashed everywhere which can be a breeding place for mosquitoes and malaria (Solomon-Ayed et al., 2011). Jimu (2004) adds that street vendors generate excess litter which stretches the capacity of sanitation department to keep cities clean.

\section{Strategies to resolve Challenges faced by Street Vendors}

The government of Botswana provides assistance to Small Micro and Medium Enterprises (SMMEs) through various schemes for citizen empowerment as represented by Financial Assistance Policy (FAP) which was replaced by Citizen Entrepreneurial Development Agency (CEDA), Botswana Development Corporation and the Micro-credit Fund. These programs put emphasis on provision of financial assistance (LEA, 2007; Pansiri and Temtime, 2008). Financial Assistance Policy (FAP) was introduced in the early 1980s to provide direct government financial assistance to small scale manufacturers (Narayan et al., 2004; BIDPA. 2011). In the late 1980s, the Integrated Field Services (IFS) was launched as a program of training for SMMEs in record keeping, costing, business planning, marketing, buying and stock control (Narayan et al., 2004; BIDPA and CEDA, 2007; BIDPA, 2011).

In 1999 the government set up the Small Business Promotion Agency (SBPA) to coordinate all Small, Medium and Micro enterprises (SMMEs) support programs; this action was followed in 2001 by the establishment of CEDA as the implementing agency of FAP, now refocused on providing subsidized loans to indigenous enterprises (BIDPA, 2011). CEDA's micro-lending activities were intended to complement those of the National Development Bank (NDB), which has provided a range of regular-term loans to SMMEs since 1999 (LEA, 2007; BIDPA and CEDA, 2007).

Local Enterprise Authority (LEA) is a government intervention which was set up in 2006 to spearhead development and growth of SMMEs and to incorporate the functions of the IFS and the SBPA (LEA, 2007). Furthermore, LEA promotes these developments through provision of training, facilitation of access to finance and markets and identifying business opportunities for existing and future SMMEs (LEA, 2007; BIDPA, 2011). Unfortunately, none of these or the earlier programs has significantly reached micro enterprises especially street food vendors.

Although Botswana does not have a comprehensive informal sector development policy, Botswana realized the potential and importance of Small, Medium and Micro enterprises (SMMEs) in creating jobs and generating income (Narayan et al., 2004). Taking into account the socio-economic objectives incorporated in the National Development Plans, Botswana's SMMEs policy, first of its kind was approved in 1998 as an integral part of the government's strategy for industrial development and economic diversification with the intention of developing informal sector (Gobagoba and Littrell, 2003; Narayan et al., 2004; Kuruba, 2010). This policy is the result of the recommendations of the SMME Task force appointed by the then Minister of Commerce and Industry (Kuruba, 2010). Though the policy is not specific to the development of the informal sector, the policy at least provides for a framework within which the informal sector can be nurtured (Narayan et al., 2004). Furthermore, the policy is 
meant not only to create an enabling environment within which SMMEs will flourish but also to grow and eventually become self-sustaining.

\section{Research Methodology}

The study applied cross sectional survey design because it gathers large data in a particular time and one can make generalizations about the outcomes as it moves from general to specific (Obasi, 1999). In addition, survey design is a common strategy used in business and management studies (Saunders et al., 2009).

The survey instrument comprised of 51 item questionnaire with mostly closed questions so as to ensure precision in responding within limited time frame. The respondents were asked to rate questions in the survey instrument using a 5-Likert scale where $5=$ was strongly Agree to $1=$ strongly Disagree. Open ended questions were used at the end of the closed ended questions to get additional information not captured in the closed ended questions. First the survey instrument was piloted tested with 5 experts in field of management to ensure that the wording of questions in the instrument captures the core elements of the study. Finally, the corrections were factored in the survey instrument before final distribution of the questionnaires to the sample of the study.

Data was analyzed using the Statistical Package for Social Sciences (SPSS) software and Microsoft Excel. Descriptive statistics comprised of frequencies; percentages; cross tabulations and chi-square to test the significance of differences and measure of relationship were done (Kumar, 2005). Correlation techniques were used to explain the relationship between variables such as cross tabulations and chi-square. Qualitative data was analyzed by content analysis.

\section{Findings and Discussions}

\section{Demographics of respondents}

One hundred questionnaires were distributed to the selected sample of the study. Out 100 questionnaires distributed 97 questionnaires were returned. Therefore, the response rate was $97 \%$. The males comprised of $23.7 \%(n=23)$ and females were $76.3 \%(n=74)$. These findings are in consistent with other previous studies which confirm that women are the largest group in street vending (Ohiokpehai 2003, Akinyele, 1987; Gobagoba and Littrell, 2003; Jimu, 2004; ISS, 2009; Acquah and Mosimanegape, 2007; Joseph 2011). The results indicated that most of these street food vendors were in the Main mall as they made up to $49.5 \%$ and the majority of them were single as evident by the $54.6 \%$ of the respondents.

Majority of respondents were the young generation of the age group 21 to 40 which accounted for $84.5 \%(\mathrm{n}=82)$. The study found out that graduates were also engaged in street food vending; however, they have contributed to $14.4 \%$ of respondents and their reasons for engaging in such trade was due to lack of employment opportunities upon graduation. Most street food vendors have attained basic education as $95.9 \%(n=93)$ have gone up to secondary education. This is also supported by Chukuezi (2010) who stated that most street food vendors in Nigeria were female respondents and have acquired tertiary education. The results indicate that $85.6 \%$ of street food vendors were not legally registered and traded without licenses. Only a $14.4 \%$ of the respondents were registered with the city council.

\section{Importance of Street Food Vending}

The major finding on the importance of street food vending is that it is a livelihood strategy for the unemployed urban poor and this accounted for (97)100\% of all respondents as indicated in Table 1. Moreover, $99 \%$ of the respondents agreed that street food vending improves lifestyle of the business owner as well as that of households and contributes to crime reduction which usually comes as a result of unemployment. The findings are in consistent with Farrington et 
al., (1986) who pointed out that crime rates are higher during periods of unemployment therefore, engaging in street trade assist in crime reduction.

The results also reveal that some of the households were involved in this business to supplement income from formal employment. In Botswana there is a high unemployment; therefore, engagement in such micro economic businesses has proved to be a source of employment as affirmed by $96.9 \%$ of the respondents. Therefore, (94)96.9\% of the respondents were engaged in street food vending as a way of promoting self-reliance. This finding is consistent with Tiwari (2002) posits that many populations in African, Asian and Latin countries who cannot find work in the formal sector have a mandate to create employment for them. Furthermore, most of the respondents are of the view that self reliance help in reduction of population's dependency on government packages and handouts for the destitute. It is clear from Table 2 that more than half of street food vendors viewed street vending as a source of employment. Hassan et al., (2011) correlates with this study's findings that informal sector contributes to employment formation as well are creating job opportunities for others. In Nigeria's street food vendors are considered as base of subsistence income (Chukuezi, 2010). The street food vending trade has been found to be lucrative for most of the population to be engaged in the same business because it is easy to join as compared to formal employment. It further removes people from poverty (Gobagoba and Littrell, 2003; Ohiokpehai, 2003).

Table 1: Importance of street food vending in Gaborone

\begin{tabular}{|c|c|c|c|c|c|}
\hline & $\begin{array}{l}\text { Strongly } \\
\text { disagree }\end{array}$ & Disagree & Neutral & Agree & $\begin{array}{l}\text { Strongly } \\
\text { agree }\end{array}$ \\
\hline $\begin{array}{l}\text { Street vending is a source of } \\
\text { employment }\end{array}$ & - & - & $3(3.1 \%)$ & $36(37.1 \%)$ & $58(59.8 \%)$ \\
\hline $\begin{array}{l}\text { Contributes to economy } \\
\text { development }\end{array}$ & $1(1 \%)$ & $1(1 \%)$ & $32(33 \%)$ & $47(48.5 \%)$ & $16(16.5 \%)$ \\
\hline $\begin{array}{l}\text { Livelihood strategy for the } \\
\text { unemployed urban poor }\end{array}$ & - & - & - & $45(46.4 \%)$ & $52(53.6 \%)$ \\
\hline $\begin{array}{l}\text { Source of income for family } \\
\text { households }\end{array}$ & - & - & $2(2.1 \%)$ & $66(68 \%)$ & $29(29.9 \%)$ \\
\hline $\begin{array}{l}\text { A way of life for the } \\
\text { unemployed }\end{array}$ & - & - & $2(2.1 \%)$ & $52(53.6 \%)$ & $43(44.3 \%)$ \\
\hline $\begin{array}{l}\text { Improves lifestyle for the } \\
\text { business owner }\end{array}$ & - & - & $1(1 \%)$ & $36(37.1 \%)$ & $60(61.9 \%)$ \\
\hline $\begin{array}{l}\text { Improves lifestyles of } \\
\text { households }\end{array}$ & - & - & $1(1 \%)$ & $36(37.1 \%)$ & $60(61.9 \%)$ \\
\hline $\begin{array}{l}\text { Provide alternatives for } \\
\text { subsistence living to formal } \\
\text { employment }\end{array}$ & - & - & $2(2.1 \%)$ & $37(38.1 \%)$ & $58(59.8 \%)$ \\
\hline Individual empowerment & - & - & $2(2.1 \%)$ & $54(55.7 \%)$ & $41(42.3 \%)$ \\
\hline $\begin{array}{l}\text { A way of diversifying the } \\
\text { economy from mining and } \\
\text { agriculture }\end{array}$ & - & $1(1 \%)$ & $13(13.4 \%)$ & $38(39.2 \%)$ & $45(46.4 \%)$ \\
\hline & & & & & \\
\hline
\end{tabular}




\begin{tabular}{|l|l|l|l|l|l|}
\hline $\begin{array}{l}\text { Promotes a culture of } \\
\text { self-reliance }\end{array}$ & & $2(2.1 \%)$ & $1(1 \%)$ & $33(34 \%)$ & $61(62.9 \%)$ \\
\hline \begin{tabular}{l} 
Contributes to crime reduction \\
\hline
\end{tabular} & - & $1(1 \%)$ & - & $31(32 \%)$ & $65(67 \%)$ \\
\hline
\end{tabular}

Source: Author's Field Data (2012)

Due to the fact that agriculture has become unreliable because of erratic rainfall, street food vending may be a way of diversifying the economy which has been highly dependent on mining. This is affirmed by $85.6 \%$ of the respondents who stated that street food vending is a way of diversifying the activities of the economy. Furthermore, $65 \%$ of the respondents consented that street food vending has significance to the nation through contribution to national economic development and improvement of the urban poor. These findings correlates with Onyuma et al., (2006) who stated that informal sector empowers the unemployed through training and technical assistance to manage their businesses. Street trading is crucial to individual empowerment and economic diversification (Pansiri and Temtime, 2008; Chen, 1997).

\section{Inferential Statistics}

Inferential statistics such as the Pearson chi-square was employed in order to determine whether there were any statistical significant differences and relationships between three demographic variables and the three importance of street food vending and the results are presented in Table 2. The level of significance was 0.05 ; if $p$-value is less than .05 then there is significant difference between variables and when $p$-value is more .05 then there is no significant difference between variables.

Table 2: Perception on Importance of street food vending verses Demographics

\begin{tabular}{|l|l|l|l|}
\hline \multicolumn{1}{|c|}{ Variable } & \multicolumn{3}{c|}{ P value (Chi-square) } \\
\hline & Age & Gender & Marital status \\
\hline $\begin{array}{l}\text { Street vending is a source of } \\
\text { employment }\end{array}$ & $\mathbf{0 . 6 4 6}$ & $\mathbf{0 . 4 4 4}$ & $\mathbf{0 . 5 5 3}$ \\
\hline Improves lifestyles of households & $\mathbf{0 . 8 6 9}$ & $\mathbf{0 . 1 6 2}$ & $\mathbf{0 . 9 5 8}$ \\
\hline Contributes to crime reduction & $\mathbf{0 . 9 2 1}$ & $\mathbf{0 . 0 0 6}$ & $\mathbf{0 . 3 5 9}$ \\
\hline
\end{tabular}

Source: Author's Field Data (2012)

The chi-square test results from cross tabulation between age and street vending as a source of employment was 0.646, improving lifestyles of households was 0.869 and contribution to crime reduction was 0.921 . All these showed that $\mathrm{p}$-value was greater than 0.05 . The results showed that there was no statistical significant difference and indicates that respondents of various ages had no different perceptions on street vending as source of employment, contributing to crime reduction and improving lifestyles of households.

A cross tabulation between marital status and all three importance of street food vending showed a p-value that was greater than the level of significance of 0.05 . It thus showed no statistical significance. This meant that there was no relationship between the respondents' marital status and how they viewed or perceived the importance of street food vending. 
The chi-square test results from gender in relation to street food feeding as a contributor to crime reduction yielded p-value of 0.006 which was less than the level of significance of 0.05 . This indicated a significant difference and suggested that respondents of different gender had different perceptions on street vending as a contributor to crime reduction.

\section{Challenges Faced By Street Food Vendors in Gaborone}

The finding indicated that street food vendors are faced with many challenges because of neglect and lack of support from public policies (Acquah and Mosimanegape, 2007). The results indicate that the major challenges that street food vendors were faced with was council bye-laws that made it illegal for them to operate in any available land and these accounted for $94.8 \%$ of the respondents. According to Gaborone City Council Commercial Officer, council laws do not recognize street food vending therefore they are denied registration and viewed as illegal operators. Consequently, these vendors then locate themselves anywhere conducive to run their businesses. This has led to council authorities' confiscating street food vendors' business items and they are fined to have their goods back.

Street food vendors raised an issue that these fines on the long run bring their businesses to a fall as they use money from the business's coffers to clear the fines. Furthermore, frequent confiscation of goods of street food vendors by council authorities has led to poor performance of these businesses. For instance, street food vendors who sells items such as hot dogs confirmed that their property such as gas cylinder have been previously been taken by council authorities because they argue that we pollute the environment and poses as a danger to the public because these flammable gases are usually exposed to the sun leading to a possibility of exploding. This finding is consistent with Joseph (2011) argued that street vendors experienced casual attacks by bye-law officers. Similarly Chukuezi (2010) posits that street food vendors complained of harassment by government officials.

An unpredictable bad weather condition was rated by $91.7 \%$ of the respondents as a challenge to street food vendors. Most respondents pointed out that during the rainy seasons they temporary close their business down and open when the situation improves. $90.7 \%$ of the respondents asserted that competition was very high because street food vendors tend to provide same product consequently leading to too much competition, which sometimes led to closure of some businesses and even reducing prices as strategy to counter competition. The finding is similar with Chukuezi (2010) who identified competition as a challenge faced by most of the street food vendors. In Kenya Street businesses are also faced with high intensity competition (Ikiaria, 2001). Butale (2001) consents that competition from foreigners businesses towards local street vendors is a major challenge.

Many street food vendors assumed that local authorities reflect anti-vending approach as $83.5 \%$ of the respondents were in agreement of such attitude. This finding is consistent with Joseph (2011) who argued that street vendors are not involved in planning more especially in their area of operation. $66 \%$ of the respondent's consented that to get space for business operations was a problem to most street vendors and therefore, used non-residential premises for business operations (Narayan et al., 2004; Lowden, 2007; ISS, 2009; BIDPA and CEDA, 2007). Gaborone City Council as law enforcement and regulatory body for street vending, has come to realize that many street food vendors crowd city centers, pavements and even passages that allow public movement. In Francistown, the acting principal bye-law officer Puso Mosimanewakgosi complained that hawkers who operated on pavements blocked movement for people in the bus rank (Masalila, 2012). 


\section{Strategies for Lessening Challenges Faced by Street Food Vendors}

For any business to move forward and push on its sales, any obstacles need to be overcome as a way to be competitive. The results indicates that $100 \%$ of the respondents rated legislation that addresses issues on street vending as an important strategy in lessening some of the challenges faced by street food vendors. In Botswana there is no specific Act or law that actually protected and guided street food vending business operations. Furthermore, for $99 \%$ of the respondent's consents that provision of training to street traders on business management and financial assistance is one way of lessening the challenges faced by street food vendors as shown in Table 3. The government has established financial support programs such as CEDA and LEA to assist informal sector businesses (Gobagoba and Littrell, 2003; BIDPA and CEDA, 2007; Kuruba, 2010).

Table 3 Results on strategies to lessen the challenges

\begin{tabular}{|l|l|l|l|l|l|}
\hline Items & Unimportant & $\begin{array}{l}\text { Not so } \\
\text { important }\end{array}$ & Important & $\begin{array}{l}\text { Very } \\
\text { important }\end{array}$ & $\begin{array}{l}\text { Most } \\
\text { important }\end{array}$ \\
\hline $\begin{array}{l}\text { Government provision } \\
\text { of training for street } \\
\text { vendors on business } \\
\text { management }\end{array}$ & $1(1 \%)$ & & $23(23.7 \%)$ & $48(49.5 \%)$ & $25(25.8 \%)$ \\
\hline $\begin{array}{l}\text { Financial assistance for } \\
\text { street vendors }\end{array}$ & $1(1 \%)$ & & $24(24.7 \%)$ & $37(38.1 \%)$ & $35(36.1 \%)$ \\
\hline $\begin{array}{l}\text { Provision of services on } \\
\text { cash basis }\end{array}$ & $2(2.1 \%)$ & $7(7.2 \%)$ & $12(12.4 \%)$ & $33(33 \%)$ & $44(45.4 \%)$ \\
\hline $\begin{array}{l}\text { Moving to areas with } \\
\text { less competition }\end{array}$ & $24(24.7 \%)$ & $36(37.1 \%)$ & $11(11.3 \%)$ & $14(14.4 \%)$ & $12(12.4 \%)$ \\
\hline $\begin{array}{l}\text { Price incentives to gain } \\
\text { competitive advantage }\end{array}$ & $16(16.5 \%)$ & $30(30.9 \%)$ & $15(15.5 \%)$ & $19(19.6 \%)$ & $17(17.5 \%)$ \\
\hline $\begin{array}{l}\text { National policies that are } \\
\text { in support of street } \\
\text { vending }\end{array}$ & $2(2.1 \%)$ & $28(28.9 \%)$ & $38(38.1 \%)$ & $30(30.9 \%)$ \\
\hline $\begin{array}{l}\text { Building of market stalls } \\
\text { in areas viable for } \\
\text { business }\end{array}$ & $2(2.1 \%)$ & $15(15.5 \%)$ & $10(10.3 \%)$ & $41(42.3 \%)$ & $29(29.9 \%)$ \\
\hline $\begin{array}{l}\text { Regulations that protect } \\
\text { all business operations }\end{array}$ & & $2(2.1 \%)$ & $22(22.7 \%)$ & $40(41.2 \%)$ & $33(34 \%)$ \\
\hline $\begin{array}{l}\text { Provision of business } \\
\text { support programs }\end{array}$ & $2(2.1 \%)$ & $23(23.7 \%)$ & $40(41.2 \%)$ & $32(33 \%)$ \\
\hline $\begin{array}{l}\text { Legislation that address } \\
\text { issues on street vending }\end{array}$ & & & $18(18.6 \%)$ & $35(36.1 \%)$ & $44(45.4 \%)$ \\
\hline Source Authors Fied $192 a(2012)$ & & & & \\
\hline
\end{tabular}

Source: Author's Field Data (2012)

Key: $1=$ Unimportant, 2 = Not so important, $3=$ Important, $4=$ Very important, $5=$ Most important

About $97.7 \%$ of the respondents believed that provision of business support programs was considered important in assisting street food vendors to overcome their difficulties that they were faced with. They also called for regulations that can protect all business operations regardless of their size. This is because government more often assisted medium enterprises as compared to micro enterprises like street vendors (BIDPA, 2007). Provision of products on 
cash basis of products as a strategy accounted for $90.7 \%$ of street food vendors and most of them preferred to provide their services on cash. They alleged that having regular loyal customers assisted in that regard. These findings is consistent with Aquah and Mosimanegape (2007) posits that street vendors suggested that location for a business was an ideal decision and therefore, need to be located at the right place and never to sell on credit.

Lack of space has been viewed as a challenge by most street vendors; therefore, $82.4 \%$ of the respondents held that it is important for local authorities and government to build them market stalls where they could operate their businesses. Moreover, it was viewed as a way that could help and protect them from bad weather and where government control could be feasible.

\section{Conclusion and policy implications}

This study gives an overview of challenges that street food vendors are faced with. And confirms that Street food vendors business are faced with many multiples problems especially the council by laws which are not friendly.

Street food vending is major income provider for households in Gaborone. Most of the respondents solely depend on Street vending income for their survival. Rural-urban migration has also impacted on available jobs and the market has become saturated. Most of urban populace has turned to street food vending as a way to survive in the city. Furthermore, the growth in street food vending has brought about environmental effects and competition of the business market.

Street food vending has become a livelihood plan for the unemployed urban habitants. Thus street food vendors businesses have made a larger part of the informal sector and therefore, their existence need to be appreciated and documented. In particular there is no precise information of how many street food vendors are registered and operational. Provision of this information would assist in recognizing and legalizing street food vending and to provide appropriate assistance.

\section{Recommendation}

The study recommends that

- Legislation which recognizes street food vendors should be reviewed, if none then it ought to be put in place so that they can also enjoy the benefits of being protected. This calls for equal treatment of all business regardless of their size of operations. Policies and laws on regulating street vendors should be put in place.

- There is no exact number of recorded street food vendors because of their unstructured manner. Most of available information is limited and most of it is outdated. Therefore, there is need for having proper documentation of street food vending businesses to assist in planning.

- Training of street food vendors and information accessibility should be of priority as most street food vendors have not received formal training.

- Private and public employers need to create employment opportunities for the skilled youth as well as providing business relevant education. This could assist in making business owners sustain and grow their businesses.

- The government needs to build permanent structures and allow street food vendors to operate on the streets because that is where business is viable.

\section{Implications of the Study}

The results of this study have imperative implications on the appropriate laws and programs aimed at improving standards of street food vendors. Registration of vendors should be well documented for ease supervision. There is need for reviews on city plans to cater for street vending needs. This was because the results showed that most urban planning strategies 
showed anti-vending attitude. Therefore, recommend for legislation that is in support of street food vending.

These findings inform policy makers the significance of street food vending as micro enterprises to those who depend and sustain their families with income from street trading.

The findings will also provide policy makers, researchers and academics literature that will assist them in reviewing available legislation on street vending. The study contributes to awareness and improves practices in the management of micro enterprises.

\section{Limitations of the Study}

The identification of street food vendors was problematic as they sold at unspecified times and located in an unstructured way. Some of the street food vendors were not licensed and feared victimization and did not want to be interviewed. Statistics on street food vendors and other micro enterprises was not available as most of the existing ones were estimates and outdated. The whole sample was not covered; however, the sample size studied was small to make generalizations to the whole population of street food vendors in the country. The fact that street food vending is not legally recognized it was difficult to have a reliable sample and conveniently sampled street vendors on the group. Moreover, due to time limitations of having to complete the study in limited period the researcher conveniently chose respondents from the three malls. Financing of the research was also a limitation as there were limited funds to be used for the project.

\section{Direction of Future Study}

Future researchers should involve in a large sample size of street food vendors and cover at least the whole of Gaborone city. There is need for a comparative study to be carried out on street food vendors business with other business in the selected malls. Further there need for one to investigate the relevance of street food vending in general in Botswana economy as whole. 


\section{References}

Acquah and Mosimanegape B. (2007). Factors contributing to the Performance of Small Business Enterprises in Botswana: A Case Study of Gaborone and Environment. Department of Economics, University of Botswana

Adekunle B. (2008). The Relationship between credit characteristics and micro enterprises performance; A brief analysis. A paper from School of Environmental Design and Rural Development. University of Guelph

Agyapong D. (2010). Micro, Small and Medium Enterprises' Activities, Income level and Poverty Reduction in Ghana: A synthesis of related literature. International Journal of Business Management. 5 (12): 198-205

Akinyele I. (1987). Study on street vendors in Ibadan, Nigeria: Characteristics offood vendors and consumers- implications for quality and safety. Rome, University of Ibadan

Arambullo P, Almeida C.R, Cuellar J.S and Belotto A.J. (1994). Street food vending in Latin America. A Special Report, Bulletin of PAHO. 28(4): 343-354

Baumgartner R.J. (2005). Sustainable Business Management: Conceptual Framework and Application

Bell J. (2005). Doing your research project: A guide for first time researchers in education, health and social science, $4^{\text {th }} \mathrm{ed}$. England, Open University Press

Bharan N. (2004). Employment and poverty alleviation. Ministry of Urban, Government of India

Bhat G.M and Nengroo A.H. (2013). Urban Informal Sectors: A case of street vendors in Kashmir. International Journal of Management and Business Studies. 3(1): 112-115

Bhowmik S.K. (2003). National Policy for Street Vendors. Economic and Political Weekly. 38 (16): 1543-1546

BIDPA and CEDA (2007). Performance and Competitiveness of Small and Medium sized manufacturing Enterprises in Botswana, BIDPA

BIDPA (2011). Promoting Entrepreneurship in Botswana: Constraints to Micro Business Development, BIDPA

Botswana Central Statistic Office. Labour Force Report 2005/06 (2007). Gaborone, Department of Printing and Publishing Services

Botswana Central Statistic Office (1999) Informal Sector Survey for 1999. Gaborone, Department of Printing and Publishing Services

Botswana Central Statistic Office (2009) Informal Sector Survey for 2007. Gaborone, Department of Printing and Publishing Services

Botswana Government Paper No.1 of 1999 (1999). Policy on Small, Medium and Micro Enterprises in Botswana, Gaborone, Government Printer

Bunjun, K.N. (1988) Consultancy report on progress of successful African women entrepreneurs: Kenya.Nairobi. UNICEF

Butale H.S. (2001). Urban Informal Sector Profile, Linkages and Constraints: A case of Francistown, Botswana. MSC Dissertation, University of Botswana

Carr, M. (1997) New Patterns: Process and Change in Human Geography. London, University Press

Central Statistics Office (2005). Enterprises and establishment register digest. Gaborone, Government Printer

Chukuezi C.O. (2010). Entrepreneurs of the Streets: Socio-Economic Features of Street Food Vending in Owerri, Nigeria. European Journal of Social Sciences. 14 (2): 183-188

Cohen M and Chen M. A (1997). A guide for assessing the impact of micro enterprise services at the individual level. Washington, AIMS 
Dardano, C. (2003). Carribbean regional working group on street food vendors, Report of FAO, PAHO and BNSI. ftp:ftp.fao.org/es/esn/food/carribean_report.pdf [Accessed 01/04/2012]

Dawson C (2002), Practical Research Methods, New Delhi, UBS Publishers Distributors Draper A. (1996). Street Foods in Developing Countries: The potential for micronutrient fortification . London School of Hygiene and Tropical Medicine

Farrington D.P, Gallagher B, Morley L, Ledger R.S and West D.J. (1986). Unemployment, School Leaving and Crime. The British Journal of Criminology. 26 (14): 335-356

Farrington J. (2001). Sustainable Livelihoods, rights and the new architecture of Aid. Natural Resource Perspectives. Number 69, London

Flower P. (2009). Research Philosophies: Importance and Relevance. Msc by research. Leading learning and Change. Cranfield School of Management

Fuller-Love N. (2006). Management Development in Small Firms. International Journal of Management Reviews. 8(3): 175-190.

Gobagoba M.R and Littrell M.A (2003). Profiling Micro Apparel Enterprises in Botswana: Motivations, Practices, Challenges \& Success. Clothing and Textiles Research Journal. 21 (3): 130-141

Gwebu T.D. (2005). Employment Creation through SMEs in Sub-Saharan Africa: Emerging Insights and Challenges from Botswana. Department of Environmental Science, University of Botswana.

Harvie C. (2003). The Contribution of micro enterprises to economic recovery and poverty alleviation in East Africa. Faculty of Commerce-Economics Working Paper, University of Wollongong

Hassan N.B, Chin S.T.S, Yeow J.A and Ron N.A.B.N. (2011). Financial Constraints and opportunities of micro enterprises entrepreneurs: A theoretical Framework. Vol: 1, Kuala Lumpur, IACSIT Press

Holden M.T and Lynch P. (2004). Choosing the appropriate, understanding research philosophy. The Marketing Review. 4: 397-409

Ikiaria B (2001). Employment Creation in Botswana: Lessons from Kenya, Mauritius and Zimbabwe- the case of Mauritius. UNDP, Knowledge Facility Project

Jefferies K. ( 2000). The New Policy on Small, Medium and Micro Enterprises, Special Briefing.BIDPA,Gaborone.http:/www.bidpa.bw/doc/bipa_briefing/SPECIAL\%20BRIEFING \%20-\%20SME\%20POLICY.PDF[accessed 28/09/10].

Jimu I.M. (2004). An Exploration of street ending's contribution towards Botswana's Vision of Prosperity for all by 2016. Pula: Botswana Journal of African Studies. 18 (1): 19-30

Joseph, M. C. (2003) Urban planning aspects of street vending in Gaborone city, Botswana (MPhil Thesis). Department of Architecture and Planning, University of Botswana.

Joseph M.C (2011). The struggle to belong; dealing with diversity in $21^{\text {st }}$ century urban settings. Paper presented at the International RC21 Conference, University of Johannesburg

Kumar R. (2005). Research Methodology-A Step-by-Step Guide for Beginners, $2^{\text {nd }}$ ed. Singapore, Pearson Education

Kuruba G (2010). Training in Business Entrepreneurship skills through distance learning. Paper submitted for presentation at the $6^{\text {th }}$ Pan Commonwealth forum on open learning Centre for Continuing Education, University of Botswana

LEA (2007). Small, Medium and Large Enterprises Database, Sector Mapping and Validation in Botswana: Findings and strategies for Local Enterprise Authority in the Republic of Botswana. Gaborone, LEA

LEA (2009). Needs assessment for SMMEs sector and business development service providers; Final Report. Gaborone, LEA 
Leighton, P. and Folstead, A. (1992) The new entrepreneurs: self management and small business in Europe. London. Kogan Page.

Linden E. (1993). The role of the informal sector. NEPRU Working Paper No.33, Windhoek, Namibia

Lowden J.S (2007). Managerial skills for the entrepreneur. Emerald Backfiles. 26(4): 35-39

Masalila W. (2012). Hawkers crowd Francistown bus rank. Daily News. No.9; 06

Matlay H. (1999). Employee relations in small firms: a micro-business perspective. Employee Relations. 21 (3): 285-295

Ministry of Commerce and Industry (1998). Policy on Small, Medium and Micro Enterprises in Botswana, Gaborone, Government Printer

Mitullah W. V. (2003a) Street trade in Kenya: contribution of research in policy dialogue and response. Paper presented to the Urban Research Symposium for Urban Development and Economic Growth, World Bank, Washington, DC

Mitullah W.V. (2003b) Street vending in African cities: A synthesis of empirical findings from Kenya, Cote D'ivoire, Ghana, Zimbabwe, Uganda and South Africa. WIEGO, Institute of Development Studies, University of Nairobi

Mmusi P. (1995). The significance of small businesses. In Briscoe, A. (Ed.) Small business support in Botswana. Gaborone. Morula Press.

Mokgosi K (1997). A study of informal trading in Gaborone, Thesis in the Faculty of Social Science, Department of Sociology, University of Botswana

Monnaesi T.T (2011). A description of whether the objectives of the performance management system of the Botswana Department of Tribal Administration are being realized. Partial degree of Master in Public and Development Management, Stellenbosch University

Moser C. (1998) 'The asset vulnerability framework: Reassessing urban poverty reduction strategies'. World Development 26 (1): 1-19

Mpuchane S.B, Gasha J, Allotey E, Collison H and Masheka J (2001). Street vendered foods-Poison and Pleasure. Presented at the conference on Promoting Food Safety in Africa organized by Food Safe Intern (FSI) in collaboration with Chartered Institute of Environmental Health (CIEH), Gaborone, Botswana

Muinde O.K and E Kuria (2005) Hygienic and Sanitary practices of vendors of street foods in Nairobi, Kenya. African Journal of Food Agriculture and Nutritional Development. 5(1): 1-13 Mukras, M.S. (2003). "Poverty Reduction Through Strengthening Small and Medium Enterprises”, PULA Botswana Journal of African Studies. 17(2): 58-69.

Muzaffar, A. T, Huq, I and Mallik, B. A (2009) Entrepreneurs of the Streets: an Analytical Workonthe Street Food Vendors of Dhaka City, International Journal of Business and Management. 4(2): 80-88

Mwangi A. (2002). Nutritional hygienic and socio-economic dimensions of street vendors in urban areas: the case of Nairobi. Dissertation No. 3157, Wageningen University

Narayan N, Kaino D.K and Sekwati L. (2004). Informal sector experiences of developing and transitional economies: What lessons can Botswana learn? Department of Economics, University of Botswana

Nasinyama, G. W. (1992). Study on street foods in Kampala, Uganda. Rome and Kampala: FAO and Makerere University.

Ndhlovu P.T. (2011). Street vending in Zambia: A case of Lusaka District. Research Paper. Graduate School of Development Studies. International Institute of Social Studies, Zambia Niehof, A. (2004). The significance of diversification for rural livelihood systems. Food Policy 7. 29(4): 321-33

Obasi I.N(1999). Research Methodology in Political Science. Nigeria, Academic Publishing Company 
Oberai A.S. (1992). Population Growth, Employment and Poverty in Third-world mega-cities. The Courier 131: 64-66

O'Dwyer M and Ryan E. (2000). Management Development Issues for owners/managers of Micra-Enterprises. Journal of European Industrial Training. 24(6):345-353

Ohiokpehai O. (2003). Nutritional Aspects of Streetfood in Botswana. Journal of Nutrition. 2(2): $76-81$

Onyuma S.O, Birachi E.A, Cheruiyoit T.K and Icart A.E. (2006). Effects of management products: Evidence from Kenya. African Journal of Business and Economics. 1 (1): 33-65

Ortiz J (2004). Rethinking the Approach to the Microenterprise sector in Latin America: An Intergrating Framework. Journal of Microfinance.3(2): 87-106

Pansiri J and Temtime Z.T. (2008). Assesing Managrial Skills in SMEs for Capacity Building. Journal of Management Development. 27 (2):251-260

Palmer, R. (2007) Skills for work?: From skills development to decent livelihoods in Ghana's rural informal economy. International Journal of Educational Development 27. 397-420

Post, J. (1996) Space for small enterprise: Reflection on urban livelihood and urban planning in Sudan. Amsterdam, Thesis Publisher

Republic of Botswana (2012). Budget Speech. Ministry of Finance and Development Planning, Gaborone, Government Printing and Publishing Services

Richardson P, Howarth R and Finnegan G. (2004). The challenges of Growing Small Businesses: Insight from Women Entrepreneurs in Africa. SEED Working Paper No.47, Series on Women Entrepreneurship Development and Gender Equality

Saha D. (2011). Working life of street vendors in Mumbai. The Indian Journal of Labour Economics. 54(2): 301-325

Saunders M, Lewis P and Thornhill A. (2009). Research Methods for Business Students $\left(5^{\text {th }}\right.$ ed). Harlow, FT Prentice Hall

Scholz R.W and Tietje O. (2002). Embedded Case Study Methods: Integrating Quantitative and qualitative Knowledge. London, Sage

Sekaran O (2003). Research methods for business; A skill building approach, $4^{\text {th }}$ ed. New York, John Wiley \& Sons

Sekar H.R. (2007). Vulnerabilities and insecurities of informal sector workers: A study of street vendors. V.V Giri National Labour Institute, NOIDA

Solomon-Ayeh B.E, King R.S and Decardi-Nelson I. (2011). Street vending and the use of urban space in Kumasi Ghana.

dspace.knust.edu.gh:8080/jjspui/.../1/Surveyor\%20Journal\%203.pdf [accessed 088/04/13]

Somolekae G. (1992). Women in the informal sector and small scale enterprises: Some observations from a recent study in the informal sector and small enterprises development in Botswana. Proceedings of a National Seminar on the Informal Sector and small scale Enterprises Development in Botswana

Task Force Report. (1998). Small, Medium and Micro Enterprises. Gaborone, Government Printer

Temtime Z.T, Chinyoka S.V and Shunda J.P.W. (2004). A decision tree approach for integrating small business assistance schemes. Journal of Management Development. 23 (6): 563-578

Temtime Z.T and Pansiri J. (2005). Managerial Competency and Organizational Flexibility in Small and Medium Enterprises in Botswana. Problems and Perspectives in Management 1: 25-36

Thomola S.J, Rankhumise E.M and van Niekerk B.J. (2011). Perceptions of Small, Medium, Micro Enterprise Entrepreneur regarding Factors Contributing to Failure: A Case of Tshwane 
Metropolitan Municipality. Department of Management and Entrepreneurship, Tshwane University of Technology

Tinker, I., and M. Fruge. (1982). The street food project. Assignment Children. 57(58): 191-200

Tiwari G. (2002). Social Dimension of Transport Planning. Delhi, Indian Institute of Technology

Tripp, A. M. (1997) Changing the rules: The politics of liberalization and the urban informal economy in Tanzania. University of California Press, Los Angels and London United Nations (2003) World youth report 2003: The global situation of young people. United Nations, New York.

UNDP and BIDPA (2005). Poverty status report for Botswana: Incidence, trends and dynamics. Research Project Report, UNDP, IPC

Welman J.C, Kruger S.T and Mitchell B. (2005). Research Methodology $3^{\text {rd }}$ ed. Cape Town, Oxford University Press Southern Africa 